\title{
Leveraging Digital Technology for Better Learning and Education: A Systematic Literature Review
}

\author{
Md Nazirul Islam Sarker, Min Wu, Qian Cao, GM Monirul Alam, and Dan Li
}

\begin{abstract}
Technological integration in learning and education is an inevitable part of the ever-changing technological world. Leveraging technology is an essential part of every learning mode. While digital technology is increasing common in schools and classrooms, finding ways to improve its impact on student learning remains a challenge for researchers and practitioners. The purpose of the study is to explore and highlight recent key literature addressing the problem of how to most effectively integrate digital technology into educational setting. Because of our inclusion criteria, forty-three key studies were identified with focus on four types of integrated digital learning such as electronic learning, mobile learning, digital learning and ubiquitous learning. The study further explores that the major technology associated delivery modes are lectures, tutorials and laboratory work. Incorporating technology in the teaching-learning process can be an effective way to develop the learners and educators for better learning and education outcomes. Our review of these studies reveals a consensus that particular strategies can promote significant improvement in student learning. We examine these arguments in hopes of offering educators and policy makers a new lens for educational effectiveness.
\end{abstract}

Index Terms - Leverage, electronic learning, digital learning, mobile learning, ubiquitous learning.

\section{INTRODUCTION}

Education is the most important sector for attaining sustainable development goals (SDGs) where digital technology can play a crucial role. Nowadays digital technology has become an essential part of the learning environment. The integration of digital technology into education is necessary for leveraging better education for all by 2030 [1]. Leveraging digital technology is the access to technology for the transformation of the traditional learning system to modern and digitalized learning system [2]. Digital technology provides an opportunity to reduce the gap between traditional manner to modern learning approach as an inclusive factor with underpinning human rights and dignity [3]. Digital technology in education generally means to model which engage in information and communication technology (ICT) for supporting, enhancing and enabling the delivery of

Manuscript received February 23, 2019; revised April 30, 2019.

Md Nazirul Islam Sarker, Min Wu, and Dan Li are with School of Public Administration, Sichuan University, Chengdu 610065, Peoples Republic of China (e-mail: sarker.scu@yahoo.com,wuminhelen@163.com).

Qian Cao is with School of Public Administration, Sichuan University, Chengdu, China and Intermediate lecturer of College of Economics and Management, Hubei MinZu University, Enshi, China (e-mail: caoqiansky@163.com).

GM Monirul Alam is with Faculty of Agricultural Economics and Rural Development, Bangabandhu Sheikh Mujibur Rahman Agricultural University, Gazipur, Bangladesh (e-mail: gmmonirul79@gmail.com). education. It is actually an effect on individual or combination of various digital devices for better education. The major indicator of leveraging digital technology in education are a political commitment, curriculum, infrastructure, teaching staff and development, public participation, skills, outcome and impact [4]-[6].

In the traditional learning and education system, there is a restriction of time and place which burden the learner to satisfy the learning environment. The digital technology provides an opportunity to meet the requirements of the learning environment and solve the barriers of learning [7], [8]. Nowadays, it is an effective tool to acquire knowledge and enhancing the capacity of learning. Leveraging digital technology helps to enhance e-learning, d-learning, $\mathrm{m}$-learning and u-learning through establishing the connection among technologies related to computer, network, ICT, multi-media, and artificial intelligence [9].

On the other hand, in a digital learning environment remove the barriers of time and place of learning where learners can get an access to digital resources like a computer, mobile devices, internet, reader devices, various facilities, video tutorials, mock exam facilities, and various analytical software. Leaners and educators can get a benefit from the learning aids in almost all stages of learning. It stimulates the motivation of learning. According to McKnight et al. [10], there is a potential for the digital learning environment to enhances capacity, creativity, collaboration, autonomy and personalization. Digital learning environment also improves the learning-focused interaction and creative thinking ability. Fernandes et al. [11] argued that traditional lecture-based pedagogy can easily be transformed into a modern digital learning environment through technology.

However, some scholars have argued that technology has almost no effect or negative effect on learning and education while others have a different opinion on leveraging technology in learning and education. This study intends to address the research question "how digital technology helps learners to learn in an effective way?". In era of technology it is necessary to explore an in-depth understanding of the technological impacts on learning. So, the above research question leads to explore the effective way of integrating digital technology for better learning and education.

The remainder of the article is organized as the next section deals with the theoretical framework. The third section describes the methodology. The fourth and fifth section deal with results and discussion. The final section conclude the article with recommendations.

\section{THEORETICAL FRAMEWORK}

A number of theories have been already developed with digitalizing the learning system and education. The study 
mainly focuses on leveraging digital technology for ensuring better learning. According to Burbules \& Callister [12], "Technological change is a constellation of what is chosen and what is not chosen; what is foreseen and what cannot possibly be foreseen; what is desired and what is not". The learning environment is necessary for easy learning which mainly depend on learner and learning techniques. An interaction between teacher and learner is crucial for better learning which promotes learning through learner-centered model. This study is mainly guided by technology-focused learner-centered system framework. Learning power theory is also consulted to shape the study. Technology focused learner-centered method focuses on the procedure of adapting technology for enhancing human-learning processes. While system framework emphasizes various related factors like the context of community or school, norms, values, cultures, interaction, available technology initiatives. Some other factors like the scope of using technology, availability of technology, supporting of leadership, and institutional models.

Basak et al. [13] conducted a systematic review on e-learning, m-learning, and d-learning and revealed that electric learning (e-learning) and mobile learning (m-learning) are generally sub-set of digital learning (d-learning). They also mentioned that technology-focused learning systems are electric learning, mobile learning, and digital learning which played important role in the teaching-learning process. Kanmani \& Babu [14] conducted a study on leveraging technology in education and especially focused on the delivery method of education. They reveal that technology is an essential element of transformation of input-based education system into outcome-based education. McKnight $e t$ al. [10] conducted a study on technology use for improving learning and revealed the potential of technology-enhanced learning for what? improving the learning process. Cárdenas-Robledo \& Peña- Ayala [15] conducted a systematic review of ubiquitous learning and concluded that it is very much effective for learning as an emergent paradigm. McCutcheon et al. [16] analyzed technology implemented practices of student learning and mentioned that technology integrated learning was good for students but software implementation was a challenge for technology integrated approach. Gökalp [17] mentioned that there was a positive view of university students on information technologies. Schüler [18] conducted a study on the integration of information in a digital learning environment and mentioned that a multi-model digital learning had a positive impact on student's learning but varied between subjects. Since the internet is a main source of information so it is helpful for technology-focused learning.

Learning power can be developed through the experiences of learning organization's vision, mental model, and system thinking [19]. Basically, there are four opinions related to learning power. First one is, learning power is an ability of learning gained from the willingness of learner [20]. Second opinion is learning power is a psychological quality of learner comprising psychological structure and mental and physical ability [21]. According to the third opinion, learning power is a basic cultural quality of modern learner [22]. Fourth group scholars opinioned that learning power is an ability of learning gained from inherent characters [21], [23].

\section{Methodology}

\section{A. Research Design}

The research is based on a systematic literature review on the last twenty years. The latest information has been included for contributing the ongoing debate about the potential of technology in the changing paradigm of education. The study mainly focuses on the technology leveraged teaching-learning approach which is convenient for the learner to gain a better education.

\section{B. Search Strategy}

Literature reviews are a significant part of the development of a field [24]. It offers the opportunity to synthesize and reflect on previous research, and thus providing secure grounding for the advancement of knowledge [25]. Therefore, literatures have been extensively searched from some renowned databases such as Web of Science, Scopus, Engineering village, Springer and Science direct using important keywords like "leverage, electronic, digital, mobile, ubiquitous, learning, technology, education and teaching. The data collection and analysis for this study have been done from April to June 2018.

\section{Inclusion and Exclusion Criteria}

The systematic review has been guided by two inclusions criteria viz. a) Is this study dealt with technology-focused learning method? And b) Is this study dealt with technology integrated delivery method? The primary data related studies have been considered for criteria a) and all kinds of studies related to the delivery method have been considered for criteria b). Related systematic review studies also considered to substantiate the argument for the present study.

\section{RESUltS OF THE STUDY}

This study has been done by following the Systematic Review and Meta-Analysis (PRISMA) guidelines [26]. At first 798 documents have been found out with 17 other documents from references. Then 167 documents have been sorted after removal of duplicate and unrelated items through abstract screening. However, again 124 documents have been excluded from 167 documents for several reasons like no full text, no study focusing on leveraging technology in learning and education. Finally, forty-three documents consisting journal articles, working papers, book chapter, magazine article, and books have been reviewed to explore the potential and effective ways of leveraging technology-based learning approach for ensuring better learning and education (Fig. 1). This qualitative document selection has been done by following the checklist of the Reporting of Observational Studies in Epidemiology (STROBE) [27].

\section{A. Analysis of Technology-Based Learning}

The traditional system of teaching approaches is transformed into modern technology-based approaches. It helps educators and learners in the teaching-learning process. 
With the advancement of technology, the teaching-learning tools are increasing day by day. Modern technology helps educators and learners equipped with emerging modern technology. Some learning approaches are recommended by the scholars which support the traditional approaches to transform modern approaches by integrating technology. The study has identified nine types of approaches as input of learning such as problem-solving approach, student created content, collaborative learning, competency-based learning, active learning, blended learning, flipped learning, integrated subject matters, and distance learning (Table I).

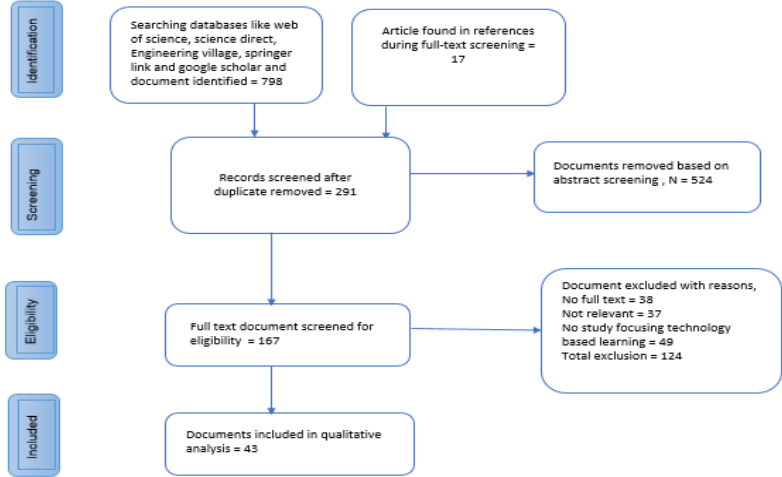

Fig. 1. PRISMA flow diagram of document selection.

TABLE 1: SUMMARY OF SELECTED STUDIES

\begin{tabular}{|c|c|c|c|c|c|}
\hline $\begin{array}{l}\text { Study } \\
\text { (year) }\end{array}$ & $\begin{array}{l}\text { sample } \\
\text { size }\end{array}$ & Research Design & Major findings & Comments & Sources \\
\hline $\begin{array}{l}\text { Chanlin et al. } \\
\text { (2006) [28] }\end{array}$ & 8 Teachers & $\begin{array}{l}\text { Quantitative approach } \\
\text { on primary data from } \\
\text { users. }\end{array}$ & $\begin{array}{l}\text { There are four factors of technology } \\
\text { leveraging learning viz. } \\
\text { environmental, personal, social and } \\
\text { curricular issues. }\end{array}$ & $\begin{array}{l}\text { Leveraging technology can } \\
\text { remove the barriers to } \\
\text { learning. }\end{array}$ & $\begin{array}{ll}\text { Innovations in } \\
\text { Education and } \\
\text { Teaching } \\
\text { International } \\
\end{array}$ \\
\hline $\begin{array}{l}\text { McLaren (2008) } \\
\text { [29] }\end{array}$ & 212 users & $\begin{array}{l}\text { uantitative approach } \\
\text { primary data from } \\
\text { ers. }\end{array}$ & $\begin{array}{l}\text { Learners had a positive perception } \\
\text { of technology-enabled teaching } \\
\text { and learning. }\end{array}$ & $\begin{array}{l}\text { Technology can solve } \\
\text { problem-based learning. }\end{array}$ & $\begin{array}{l}\text { International } \\
\text { Journal of } \\
\text { Technology and } \\
\text { Design Education }\end{array}$ \\
\hline Gökalp (2010) [17] & 395 & $\begin{array}{l}\text { ative approach } \\
\text { hary data from }\end{array}$ & $\begin{array}{l}\text { University students had quite a } \\
\text { positive view of information } \\
\text { technologies. }\end{array}$ & $\begin{array}{llrr}\begin{array}{l}\text { Students } \\
\text { perception }\end{array} & \text { had } & \text { a } & \text { good } \\
\text { learning. } & & & \text { digital } \\
\end{array}$ & $\begin{array}{l}\text { Procedia Social } \\
\text { and Behavioral } \\
\text { Sciences }\end{array}$ \\
\hline $\begin{array}{ll}\text { Chatarajupalli } & e t \\
\text { al. (2010) [30] } & \end{array}$ & $\begin{array}{l}20 \quad \text { Indian } \\
\text { states } \\
\text { covering } \\
474 \text { colleges }\end{array}$ & $\begin{array}{l}\text { Quantitative approach } \\
\text { on primary data from } \\
\text { students. }\end{array}$ & $\begin{array}{l}\text { The desired outcome can be } \\
\text { achieved through ICT integrated } \\
\text { learning. }\end{array}$ & $\begin{array}{l}\text { ICT enabled learning may act } \\
\text { as active learning. }\end{array}$ & $\begin{array}{l}2010 \text { International } \\
\text { Conference on } \\
\text { Technology for } \\
\text { Education }\end{array}$ \\
\hline $\begin{array}{l}\text { Aloraini } \\
{[31]}\end{array}$ & $\begin{array}{l}40 \quad \text { female } \\
\text { students }\end{array}$ & $\begin{array}{l}\text { Quantitative approach } \\
\text { on primary data from } \\
\text { students. }\end{array}$ & $\begin{array}{l}\text { There is a positive significant } \\
\text { relationship between the use of } \\
\text { technologies and academic } \\
\text { learning. }\end{array}$ & $\begin{array}{l}\text { Collaborative learning has a } \\
\text { good impact on academic } \\
\text { performance. }\end{array}$ & $\begin{array}{l}\text { Journal of } \\
\text { Saud Uning } \\
\text { Languages and } \\
\text { Translation }\end{array}$ \\
\hline Zuiker (2012) [32] & 5 students & $\begin{array}{l}\text { Uantitative approach } \\
\text { n primary data from } \\
\text { udents. }\end{array}$ & $\begin{array}{l}\text { Educational Virtual Environments } \\
\text { (EVEs) as a potential key for } \\
\text { understanding and leveraging } \\
\text { technology in education. }\end{array}$ & $\begin{array}{l}\text { EVEs can be a potential tool } \\
\text { for } \\
\text { learners and teachers. }\end{array}$ & $\begin{array}{l}\text { British Journal of } \\
\text { Educational } \\
\text { Technology }\end{array}$ \\
\hline $\begin{array}{lr}\text { Wentworth } & \& \\
\text { Middleton } & (2014) \\
\text { [33] }\end{array}$ & $\begin{array}{l}483 \text { students, } \\
\text { USA }\end{array}$ & $\begin{array}{l}\text { ative approach } \\
\text { ary data from }\end{array}$ & $\begin{array}{l}\text { There is a positive significant } \\
\text { relationship between the use of } \\
\text { technologies and academic } \\
\text { performance. }\end{array}$ & $\begin{array}{l}\text { Competency-based } \\
\text { education can bring a good } \\
\text { impact. }\end{array}$ & $\begin{array}{l}\text { Computers } \\
\text { Education }\end{array}$ \\
\hline $\begin{array}{l}\text { Khan \& } \text { Chiang } \\
\text { (2014) [34] }\end{array}$ & 6 students & $\begin{array}{l}\text { Quantitative approach } \\
\text { on primary data from } \\
\text { students. }\end{array}$ & $\begin{array}{l}\text { Mobile devices engagement is } \\
\text { positively related to effective } \\
\text { learning over traditional means. }\end{array}$ & $\begin{array}{l}\text { Smartphones are effective } \\
\text { devices for learning. }\end{array}$ & $\begin{array}{l}2014 \text { IEEE Global } \\
\text { Engineering } \\
\text { Education } \\
\text { Conference } \\
\end{array}$ \\
\hline $\begin{array}{l}\text { Christmann (2015) } \\
\text { [35] }\end{array}$ & $\begin{array}{l}7 \text { graduate } \\
\text { udents }\end{array}$ & $\begin{array}{l}\text { uantitative approach } \\
\text { n primary data from } \\
\text { udents. }\end{array}$ & $\begin{array}{l}\text { There was a significant difference } \\
\text { between online instruction based } \\
\text { learning and traditional } \\
\text { face-to-face learning. }\end{array}$ & $\begin{array}{l}\text { Blended learning is good for } \\
\text { learners. }\end{array}$ & $\begin{array}{l}\text { E-Learning and } \\
\text { Digital Media }\end{array}$ \\
\hline $\begin{array}{l}\text { Daud et al. (2015) } \\
\text { [36] }\end{array}$ & 1 students & $\begin{array}{l}\text { antitative approach } \\
\text { primary data from } \\
\text { Idents. }\end{array}$ & $\begin{array}{l}\text { Digital learning Perceptions was a } \\
\text { good and appropriate College } \\
\text { student. }\end{array}$ & $\begin{array}{l}\text { Digital learning approach } \\
\text { can improve the quality of } \\
\text { learning. }\end{array}$ & $\begin{array}{l}\text { Procedia - Social } \\
\text { and Behavioral } \\
\text { Sciences }\end{array}$ \\
\hline $\begin{array}{l}\text { Sevillano-Garcí \& } \\
\text { Vázquez-Cano } \\
\text { (2015) [37] }\end{array}$ & 419 students & $\begin{array}{l}\text { approach } \\
\text { data from }\end{array}$ & $\begin{array}{l}\text { The use of digital mobile devices } \\
\text { helps the student to learn at the } \\
\text { university level. }\end{array}$ & $\begin{array}{l}\text { Student created content by } \\
\text { mobile devices help them to } \\
\text { learn easily. }\end{array}$ & $\begin{array}{ll}\text { Educational } & \\
\text { Technology } \quad \& \\
\text { Society }\end{array}$ \\
\hline $\begin{array}{l}\text { Paek, Hoffman, \& } \\
\text { Black (2016) [38] }\end{array}$ & 173 students & $\begin{array}{l}\text { Quantitative approach } \\
\text { on primary data from } \\
\text { students. }\end{array}$ & $\begin{array}{l}\text { technology has a "bottom up" } \\
\text { impact on learners' ability to learn } \\
\text { new lesson. }\end{array}$ & $\begin{array}{lrr}\text { The study } & \text { focuses } & \text { on } \\
\text { design-related } & \text { issues } & \text { in } \\
\text { education. } & & \end{array}$ & $\begin{array}{l}\text { Educational } \\
\text { Technology } \\
\text { Research and } \\
\text { Development }\end{array}$ \\
\hline $\begin{array}{l}\text { Tang \& } \\
\text { (2016) [39] }\end{array}$ & $\begin{array}{l}176 \\
\text { respondents }\end{array}$ & $\begin{array}{l}\text { Quantitative approach } \\
\text { on primary data from } \\
\text { participants. }\end{array}$ & $\begin{array}{l}\text { The digital literacy had a } \\
\text { significant relationship with the } \\
\text { learning approach. }\end{array}$ & $\begin{array}{l}\text { Integration of subject matter } \\
\text { can influence the learning. }\end{array}$ & $\begin{array}{l}\text { The Electronic } \\
\text { Journal of } \\
\text { e-Learning }\end{array}$ \\
\hline $\begin{array}{l}\text { McKnight et al., } \\
\text { (2016) [10] }\end{array}$ & & $\begin{array}{l}\text { Quantitative approach } \\
\text { on primary data from } \\
\text { teachers. }\end{array}$ & $\begin{array}{l}\text { Technology can enhance teaching } \\
\text { and learning. }\end{array}$ & $\begin{array}{l}\text { Technology } \\
\text { integrated } \\
\text { strategies are good for } \\
\text { teachers and learners. }\end{array}$ & $\begin{array}{lr}\text { Journal } & \text { of } \\
\text { Research } & \text { on } \\
\text { Technology } & \text { in } \\
\text { Education } & \end{array}$ \\
\hline $\begin{array}{lr}\text { Camilleri } & \& \\
\text { Camilleri } & (2017) \\
{[40]} & \\
\end{array}$ & $\begin{array}{l}241 \\
\text { educators }\end{array}$ & $\begin{array}{l}\text { Quantitative approach } \\
\text { on primary data from } \\
\text { educators. }\end{array}$ & $\begin{array}{l}\text { The younger teachers had a good } \\
\text { confidence in } \\
\text { digital learning resources. }\end{array}$ & $\begin{array}{l}\text { The roblem-solving } \\
\text { approach has an impact on } \\
\text { educational outcomes. }\end{array}$ & $\begin{array}{l}\text { Technology, } \\
\text { Knowledge } \\
\text { Learning }\end{array}$ \\
\hline Ball et al. (2017) & 71 & Quantitative approach & ICTs help the learner to contact & Technology enabled learning & Journal of Applic \\
\hline
\end{tabular}




\begin{tabular}{|c|c|c|c|c|c|}
\hline [41] & participants & $\begin{array}{l}\text { on primary data from } \\
\text { students. nine focus } \\
\text { groups }\end{array}$ & $\begin{array}{l}\text { with geographically distant social } \\
\text { ties. Older people had a negative } \\
\text { perception of technology integrated } \\
\text { education. }\end{array}$ & $\begin{array}{l}\text { can help learners though } \\
\text { older people had a different } \\
\text { perception on it. }\end{array}$ & Gerontology \\
\hline $\begin{array}{l}\text { Schüler } \quad(2017) \\
{[18]}\end{array}$ & $\begin{array}{l}97 \\
\text { participants }\end{array}$ & $\begin{array}{l}\text { Quantitative approach } \\
\text { on primary data from } \\
\text { participants. }\end{array}$ & $\begin{array}{llr}\text { Learners can detect } & \text { the } \\
\text { inconsistencies by } & \text { using } \\
\text { technology in learning. } & \end{array}$ & $\begin{array}{l}\text { Collaborative learning } \\
\text { approach can enable the } \\
\text { learner to detect } \\
\text { inconsistencies in education. }\end{array}$ & $\begin{array}{l}\text { Learning } \\
\text { Instruction }\end{array}$ \\
\hline Stork (2017) [42] & $\begin{array}{l}34 \\
\text { respondents }\end{array}$ & $\begin{array}{lr}\text { Primary data } & \text { from } \\
\text { teachers } & \text { and } \\
\text { administrators } & \\
\end{array}$ & $\begin{array}{l}\text { Digital learning approach is good } \\
\text { for learning. }\end{array}$ & $\begin{array}{l}\text { Digital learning approach is } \\
\text { good for teacher and student. }\end{array}$ & $\begin{array}{l}\text { Journal } r \text { of } \\
\text { Formative Design } \\
\text { in Learning }\end{array}$ \\
\hline $\begin{array}{l}\text { Saxena et al. } \\
\text { (2018) [43] }\end{array}$ & 260 & $\begin{array}{l}\text { Quantitative approach } \\
\text { on primary data from } \\
\text { students }\end{array}$ & $\begin{array}{l}\text { Majority }(89.23 \%) \text { students had a } \\
\text { keen interest for implementation of } \\
\text { e-learning in their curriculum. }\end{array}$ & $\begin{array}{l}\text { It reflects the willingness of } \\
\text { students to adopt digital } \\
\text { technology in education. }\end{array}$ & $\begin{array}{lr}\text { Journal of } & \text { Oral } \\
\text { Biology } & \text { and } \\
\text { Craniofacial } & \\
\text { Research } & \\
\end{array}$ \\
\hline $\begin{array}{lr}\text { Wiklund } & \& \\
\text { Andersson } & (2018) \\
{[44]} & \end{array}$ & 650 students & $\begin{array}{l}\text { Quantitative oriented } \\
\text { qualitative mixed } \\
\text { approach on primary } \\
\text { data from students. }\end{array}$ & $\begin{array}{l}\text { Student-initiated technology had a } \\
\text { positive impact on learning. }\end{array}$ & $\begin{array}{l}\text { Student created content can } \\
\text { help the student to learn } \\
\text { quickly. }\end{array}$ & $\begin{array}{l}\text { E-Learning and } \\
\text { Digital Media }\end{array}$ \\
\hline Li et al. (2018) [45] & 11 students & $\begin{array}{l}\text { Quantitative approach } \\
\text { on primary data from } \\
\text { students. }\end{array}$ & $\begin{array}{l}\text { Technology empowered } \\
\text { student for learning. }\end{array}$ & $\begin{array}{l}\text { Integration of technology } \\
\text { help student to learn easily. }\end{array}$ & $\begin{array}{l}\text { E-Learning and } \\
\text { Digital Media }\end{array}$ \\
\hline
\end{tabular}

\section{B. Analysis of the Framework of Learning}

This section deals with the result of content analysis of the

studies which are based on systematic review. This study analyzes the studies and summarizes the results in Table II.

TABLE II: TECHNOLOGY LEVERAGED FRAMEWORK OF LEARNING IN RELATED STUDIES

\begin{tabular}{|c|c|c|}
\hline Researcher and Time & Major findings & Source \\
\hline Basak et al. (2018) [13] & $\begin{array}{l}\text { The form of technology-focused learning is electronic learning, mobile } \\
\text { learning and digital learning. }\end{array}$ & E-Learning and Digital Media \\
\hline Means (2010) [46] & $\begin{array}{l}\text { Instructional coherence and competition are major challenges of software } \\
\text { implementation. }\end{array}$ & $\begin{array}{l}\text { Journal of Research on Technolog } \\
\text { y in Education }\end{array}$ \\
\hline $\begin{array}{l}\text { McCutcheon et al. }(2017) \\
{[16]}\end{array}$ & The success of learning is varied on the distance-based instructional model. & $\begin{array}{l}\text { Currents in Pharmacy Teaching } \\
\text { and Learning }\end{array}$ \\
\hline $\begin{array}{l}\text { Kanmani \& Babu (2015) } \\
\text { [16] }\end{array}$ & Traditional teaching methods can be modified by leveraging technology. & ICTIEE 2014 \\
\hline $\begin{array}{l}\text { Cárdenas-Robledo \& } \\
\text { Peña-Ayala (2018) [15] }\end{array}$ & $\begin{array}{l}\text { Ubiquitous learning focuses emergent paradigm of learning which can } \\
\text { disseminate education in various setting. }\end{array}$ & Telematics and Informatics \\
\hline Sung et al. (2016) [47] & Mobile devices have great potential in both classrooms and outdoor learning. & Computers and Education \\
\hline Görke et al. (2017) [48] & $\begin{array}{l}\text { Mobile devices are making digital learning environment as a cost-effective } \\
\text { tool. }\end{array}$ & Procedia Manufacturing \\
\hline $\begin{array}{l}\text { Ronchetti et al. (2015) } \\
\text { [49] }\end{array}$ & Digital competence is grown through leveraging technology (e-schooling) & Encyclopedia \\
\hline $\begin{array}{l}\text { Fernandes et al. (2018) } \\
\text { [11] }\end{array}$ & $\begin{array}{l}\text { Restructure is necessary to make new professional development learning plan } \\
\text { with leveraging technology. }\end{array}$ & Research in Science Education \\
\hline Geiger et al. (2011) [50] & Digital technologies have a positive impact on teaching and learning. & $\begin{array}{l}\text { International Group for the } \\
\text { Psychology of Mathematics } \\
\text { Education }\end{array}$ \\
\hline
\end{tabular}

TABLE III: CHARACTERISTICS OF LEVERAGING TECHNOLOGY-BASED LEARNING

\begin{tabular}{|l|l|l|l|l|}
\hline $\begin{array}{l}\text { Electronic learning } \\
\text { (e-learning) }\end{array}$ & $\begin{array}{l}\text { Mobile learning } \\
\text { (M-learning) }\end{array}$ & $\begin{array}{l}\text { Digital learning } \\
\text { (D-learning) }\end{array}$ & $\begin{array}{l}\text { Ubiquitous learning } \\
\text { (U-learning) }\end{array}$ \\
\hline Computer & Mobile & Adaptive learning & $24 x 7$ hrs of learning \\
\hline Bandwidth & Bluetooth, GPRS, 3G & Badging and gamification & Bandwidth & {$[51],[52]$} \\
\hline Multimedia & Objects & Blended learning & Digitalized & [53] \\
\hline Interactive & Networked & Classroom technologies & Networked & {$[54]$} \\
\hline Hyperlinked & Situated learning & E-textbooks & Holistic & Any time \& place \\
\hline Collaborative & Realistic situation & Learning analytics & Friendly approach \\
\hline Distance learning & Constructivism & Learning objects & Collaboration \\
\hline Simulated situation & Social interaction & Mobile learning & Online & [56] \\
\hline Hyperlearning & Collaborative & Personalized learning & Informal and connected & [57] \\
\hline Media-rich & Spontaneous & Online learning & [59] \\
\hline More Formal & Connected & Open educational resources & andways \\
\hline Structured & Lightweight & $\begin{array}{l}\text { Technology-enhanced teaching } \\
\text { and learning }\end{array}$ & Unstructured \\
\hline Broadband & Informal & Virtual reality & Informal and virtual \\
\hline Intelligent & Situationism & Game-based learning & Intelligent \\
\hline Usable & Personal & Accessing digital content & Accessing digital content & {$[62]$} \\
\hline
\end{tabular}

The study reveals that there are many forms of technology leveraged learning framework. The major learning frameworks are electronic learning, mobile learning, digital learning and ubiquitous learning. Transformation is necessary for the teaching-learning process through using modern technology for ensuring a better education.

\section{Analysis of Technology Focused Delivery Methods}


The study has identified the following studies which focused the technology-based delivery methods. The major delivery methods are electronic learning (e-learning), mobile learning (M-learning), digital learning (D-learning), and ubiquitous learning (U-learning) (Table III).

\section{DISCUSSIONS}

The section deals with the research results in four parts. The first part deals with various approaches as input of learning through analyzing the studies which based on primary data (Table I), the second part describes the tools for effective technology leveraging learning, the third part deals with approaches for ensuring technology in learning based on the studies which use secondary data and systematic reviews and fourth part explains the delivery method of learning (Fig. 2).

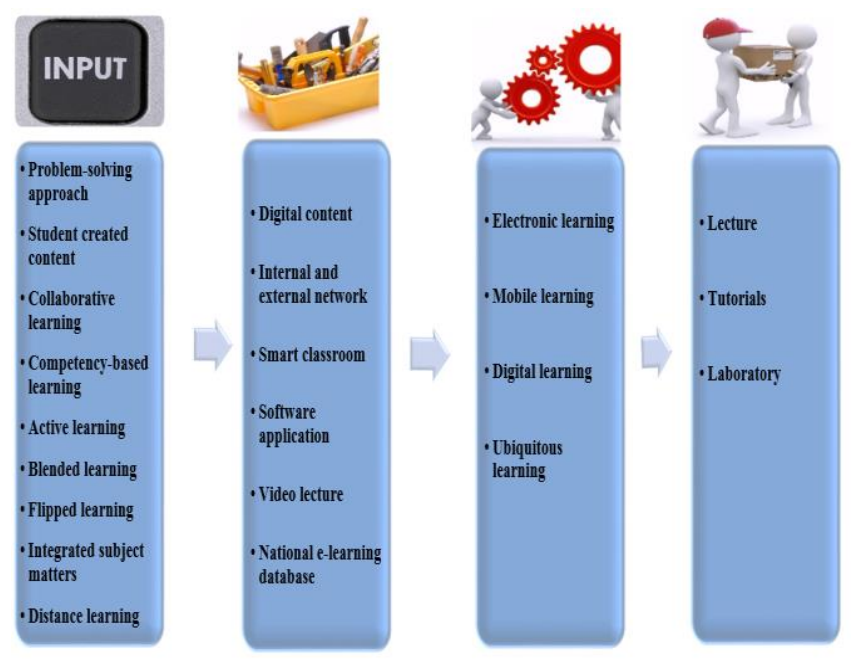

Fig. 2. Model of leveraging digital technology-based learning.

The model of leveraging digital technology-based learning is comprised four steps such as inputs, tools, approaches and delivery which have been developed through this study (Fig. 2). It deals with the whole process of the technology leveraging education. The following sections describes in details.

\section{A. Technology-Based Learning Approaches}

Technological advancement provides an opportunity to learn anywhere at any time. In the technological paradigm of education, teachers and educators are using technological approaches to teach learners. There are nine ways of technology-based approaches to learning which reveals from the systematic literature search results (Table I).

\section{1) Problem-solving based learning}

The learning should be problem-solving. If the stakeholder can find out the problem, he/she can easily solve the problem by taking technological help. It requires conceptual understanding and communication and provides an opportunity to think creatively [65]. Problem-based learning helps to build competency rather than only memorizing some texts. It also helps to prepare the learner to solve the complex problem which may face in future. Technology helps to solve the problem and gain to learn about the way of how to solve the similar problem in future with the help of technology.

\section{2) Student created content}

There are some studies done by some scholars on student-initiated digital content. It shows that students are very much curious about the technology. They can easily develop the content according to their demand and way of learning. Nowadays some institutions offer the student to content creation competition which helps to increase the creativity of the student [66]. A student can create content with the help of technology baes approaches and share with friends, within the classroom, within the school as well as online platforms. There are some web-based tools which help the student to create learning content by using their idea. It actually provides an opportunity to develop creativity, explore intelligence and share with others.

\section{3) Collaborative learning}

Various collaborative technological tools provide an opportunity to develop collaborative learning. It can be done anywhere at any time. The learner can communicate easily with peers, teachers, and learning community with the help of some communication tools like Skype, Facebook, google doc, and Dropbox and discuss the study matter with others [67]. It helps to improve creativity and learn the matter quickly, share the ideas, gain the knowledge and sharing the experiences. It can help students, learners, teachers, educators, researchers and trainers in one platform.

\section{4) Competency-based education}

Competency-based learning is developed with the help of technology. It emphasizes effective learning rather than time-based learning. Competency improvement is a major goal of learning which can be easily developed through using technology. This approach allows students and learners to learn from e-learning platform, video tutorials and e-teachers [3]. It is a transformational approach to transform student and teachers from traditional system to modern technology-based learning by removing the barriers of credit hours and teaching place and time. It is actually an advance step of learning to acquire knowledge by removing stress and time factor.

\section{5) Active learning}

Active learning approach deals with the activation of all stakeholders like students, learners, teachers, and educators. It mainly focuses to learn from experiences from each other using various learning tools and allowing themselves to think and act accordingly [68]. Teachers and trainers can act as a guide and teach the learners when needed and suggest them the tools which are effective for learning.

\section{6) Blended learning}

Blended learning means a method of learning through a combination of traditional classroom and online digital media. It requires the physical presence of educators and learners but learning materials are presented by a digital method in a computer, tablet, mobile, and other digital devices [69]. There is a provision in blended learning to include multi-model learning approaches which will be a complement to each other for effective learning. There is a significant relationship between blended learning approach and effective learning [39].

\section{7) Flipped learning approach}


Flipped learning approach focuses the increasing of student -teacher/student interaction with the help of technology in the classroom. In this approach, the student is allowed to use digital devices for learning in the classroom and retrieved information and related content at home instead of the classroom [66]. This pedagogical approach helps the student to prepare themselves at home before classes. The major four pillars of flipped learning are the flexible environment, learning culture, intentional content, and professional education.

\section{8) Integration of subject matter}

Integration approach helps the learner to learn something integrated, holistic and cross circular contents. It is actually a combination of related subject matters. One of the major characteristics of the integration of subject matter is coherence which must be focused on the learning demand of learners [70]. It is a suitable approach in ever-changing technological world. It is actually student-centred curriculum which includes learners and increasing interest.

\section{9) Distance learning approach}

Distance learning approach is considered as a means to teach a mass people at a time. It is usually designed for educating for the millions of deprived people. It is an effective method in the least developed countries. In this approach, the learner is physically separated from the teachers and the institution [54]. It is an old approach for educating people who seek knowledge. Now it is updated with technological integration. Nowadays distance learning uses technology for its lecture delivery, stored learning materials, sharing study materials, video tutorials, and assessment paper submission. Technology for Learning and Education

\section{0) Components of technology focused learning}

The modern technology-based learning uses some tools viz. computer-based training, internet, world wide web (www), video book, VoIP (voice over internet protocol), web-based training (WBT), learning management system (LMS), digital content, synchronous e-learning, asynchronous e-learning, electronic bulletin board, blog, ASP (Application service provider), animation, page turner, courseware, Notional learning time (NLT), and personal digital assistant (PDAs). The major components of technology integrated learning are digital content, internal and external networks, smart classroom setup, software application, video recording and online lecture facility, and national e-learning grid.

Digital content: Various digital content like video recording, video tutorials, 2-D, 3-D animation, and game are used by the learners.

Smart classroom setup: Smart classroom comprises a computer, digital display board, internet, desk, webcam, and sound system which hep to learn the learner very smartly.

Internal and external networks: A technology-focused learning environment must have Local Area Network (LAN), Wide Area Network (WAN), various internet-based application which should be connected to national e-Grid. Software application: various software is necessary to build technology engaged learning environment for knowledge repository, laboratory experiment, interactive games and useful application for maintaining smart desk.
Video recording and online lecture facility: It is necessary for maintaining technology-based environment. It should be easily accessible for learners from remote places. It also helps to take remote classes.

National e-learning grid: National e-learning grid is the central databases of a country which should be connected with internet, TV and radio. It helps to conduct teaching, training, learning and education for teaching the learners. It is mandatory for an educational institution.

\section{B. Approaches of Technology Integrated Learning}

\section{1) Digital learning (d-learning)}

D-learning is a technology-based learning approach which facilitates learner to get learning with control over time, place and path. It removes the barriers of time and place. In case of time, the learner is not limited to working day on holiday or even different time in a day. In the case of place, the learner is not restricted to home, school or other institution, he/she can learn anywhere. In case of a path, the learner is not limited to learn the pedagogy fixed by teacher or trainer because various digital devices help themselves to learn their own style. In case of pace, the learner is not limited to the pace of the whole classroom. It helps to utilize adaptive and interactive software to learn something. Actually, it is a combination of digital content, technology and instruction.

\section{2) Electronic learning (e-learning)}

E-learning is an abbreviated form of electronic learning which has emerged in mid-1990s. It is actually a computer and web-based learning. Any electronic form is under e-learning. It provides a quick learning facility reducing cost and time. According to Behera [55], various forms of e-learning are blended learning, online learning, m-learning and distance learning. E-learning can happen in various situations like learner and teacher are not in same place, teleconferencing, postal mail, a combination of face to face and online learning, collaboration software, personal digital assessment (PDAs), web-based courses, mobile phones and laptops. It can provide a wide range of solutions for improving knowledge. It is a personalized method highlighting online learning, mentoring, assessment and learning management system through a wide area network (WAN) and the information highway.

\section{3) M-learning}

M-Learning (Mobile learning) is a learning approach which is based on mobile devices. It is initiated in the 1960s by Alan Kay. Mobile devices are used to access information for learning. According to Lindquist et al. [71], there are five basic parameters of m-learning viz. portable, customize, social interaction, connectivity and context sensitive. It is very much convenient to carry like PDA and it can provide an opportunity to contact with other learners, teachers, colleagues, and friends. It provides a way to collect information from current place, time and learning environment as well as make strong network through mobile devices. According to Chen \& Kotz [72], mobile contexts are of four forms like computing context, time context, physical and user context. All the contexts describe network, communication, noise, temperature and time. Mohanna [73] mention that m-learning has various formats like the message, 
game, quizzes, multimedia through the integration of various software and hardware technologies. It is useful for various level of learners which can be used by various mobile devices.

\section{4) U-learning}

U-learning (Ubiquitous learning) is a relatively new concept which is applicable for learning various disciplines. It is initiated by Mark Weiser in 1980s. It is actually $24 \times 7$ hours of learning. Various electronic devices are interconnected to a communication network for effective and quick learning U-learning approach. It is actually the advance version of mobile learning which systematically progressed from e-learning to m-learning and m-learning to U-learning. It provides an opportunity to create a ubiquitous learning environment (ULE). E-learning is a new paradigm of learning which has a philosophy of anywhere, anytime and anyway to learn. It provides a way to access the learning content through a wireless network from anywhere and anytime. It helps to earn knowledge from ubiquitous learning environment at the right time, right places by the right way.

\section{Technology Focused Delivery Method}

Technology enables the delivery method as convenient, timely and right way approach. There are various forms of delivery method. The major acceptable three methods are lecture, tutorials and laboratory which commonly used in the learning environment and educational institutions.

\section{1) Lecture}

The lecture is an effective and traditional delivery method of learning. It is started from a few centuries ago. Chalk and duster were the main materials of lecture in a classroom [14]. The teacher used chalk in the classroom and talk to the student about lesson and student tried to gain knowledge from a lecture in the classroom. Students were a silent audience to hear the lecture and no right to say something during lecturing It happened regular basis in the classroom. Now the classroom environment is changing with integrating technology. The major introduced technologies for the classroom are whiteboard, overhead projector, computer, various digital devices, speaker, internet connection, and other video display facilities. Though technology has introduced in the classroom it cannot bring major changes in the teaching-learning process [67]. Actually, the approach of teaching is from teacher to student which exist from last few centuries. Though the process of teaching-learning through lecturing is well accepted by all it needs some modifications for getting the full benefit from it. A two-way communication is necessary between teacher and student for effective learning rather than a top-down approach. It should be from teacher to student and student to teacher. Technology may be a bridge in this two-way communication channel for ensuring better learning and education.

\section{2) Tutorials}

The tutorial is one of the major approaches of teaching-learning processes. It means a specific and regular guidance from instructor may be in the classroom or out of the classroom. Generally, the number of the learner in the tutorial session is less than a regular classroom. It is usually done after the class lecture or outside of class lecture. Sometimes a hybrid system like a tutorial with regular class lecture is usually found in many schools and it is known as the flipped classroom [74]. In this model, a video tutorial is given to the learner to solve the problem at home. It is now a well-accepted model in many countries. Another is found behind this model that learners are not confident enough to learn from a class lecture [63]. So, they are searching for extra teaching care from external sources like tutorial home. Leveraging technology is effective to modernize and effective tutorial home for learners.

\section{3) Laboratory}

A laboratory is a place where learners can gain the practical knowledge about the theory. It is started in $451 \mathrm{BC}$. It is a process of learning by doing. According to science, the learner can learn $5 \%$ by listening, $10 \%$ by reading, $30 \%$ by demonstration and $75 \%$ by doing. The learner cannot get any practical knowledge without attending laboratory work. Various types of experiments may be done in the laboratory [14]. Some experiments may be done under the guidance of the instructor and some are initiated by the learner themselves. It is a place to learn state-of-art knowledge. Various scientific findings are explored in the laboratory. It increases the confidence of the young learner and facilitates senior learners to innovate new research findings.

\section{CONCLUSION}

Nowadays leveraging digital technology has become a potential and key tool for ensuring better learning and education. In this research, a systematic literature review has been done to explore how digital technology can be integrated in education effectively. The study reveals that there are mainly four types of technology integrated learning methods such as electronic learning, mobile learning, digital learning, and ubiquitous learning. The study further explores that the major technology associated delivery modes are lectures, tutorials and laboratory work. The study reveals that leveraging technology is an essential part of every learning mode. The findings suggest that technology should be integrated at all levels of curriculum development, input of learning process, procedure of learning process, and delivery method for getting full benefits from technology leveraged learning method. Continuous reform and transformation are necessary for the teaching-learning process through using modern technology for ensuring a better education.

\section{ACKNOWLEDGMENT}

This article is funded by Sichuan University Innovation Spark Project (No.2018hhs-21), Sichuan University Central University Basic Scientific Research Project (No. skqx201501), Sichuan University New Century Higher Education 8th Teaching Reform Project (No. SCU8302), Chengdu Radio \& TV University Project (Learning City Construction Monitoring).

\section{REFERENCES}

[1] V. Scherman, S. J. Howie, and R. J. Bosker, "Constructing benchmarks for monitoring purposes: evidence from South Africa," Educ. Res. Eval., vol. 17, no. 6, pp. 511-525, Dec. 2011. 
[2] S. R. Hiltz and M. Turoff, "Education goes digital: The evolution of online learning and the revolution in higher education," Commun. ACM, vol. 48, no. 10, pp. 59-64, 2005.

[3] K. O. Lewis, M. J. Cidon, T. L. Seto, H. Chen, and J. D. Mahan, "Leveraging e-learning in medical education," Curr. Probl. Pediatr. Adolesc. Health Care, vol. 44, no. 6, pp. 150-163, 2014.

[4] A. Chigona, W. Chigona, and Z. Davids, "Educators'motivation on integration of ICTs into pedagogy: case of disadvantaged areas," South African J. Educ., vol. 34, no. 3, pp. 1-8, 2014.

[5] A. Botha, "A Teacher Tablet Toolkit to meet the challenges posed by 21 st century rural teaching and learning environments," South African J. Educ., vol. 35, no. 4, pp. 1-19, 2015.

[6] A. Bosman, "Learning style preferences and Mathematics achievement of secondary school learners," South African J. Educ., vol. 38, no. 1, pp. $1-8,2018$.

[7] L. Ebersöhn, T. Loots, I. Eloff, and R. Ferreira, "In-service teacher training to provide psychosocial support and care in high-risk and high-need schools: school-based intervention partnerships," J. Educ. Teach., pp. 1-19, 2015.

[8] N. De Lange, M. Khau, and L. Athiemoolam, "Teaching practice at a rural school? and why should we go there?," South African J. High. Educ., vol. 28, no. 3, Jan. 2016.

[9] S. H. Harwell, S. Gunter, S. Montgomery, C. Shelton, and D. West, "Technology integration and the classroom learning environment: Research for action," Learn. Environ. Res., vol. 4, no. 3, pp. 259-286, 2001.

[10] K. McKnight, K. O’Malley, R. Ruzic, M. K. Horsley, J. J. Franey, and $\mathrm{K}$. Bassett, "Teaching in a digital age: How educators use technology to improve student learning," J. Res. Technol. Educ., vol. 48, no. 3, pp. 194-211, 2016.

[11] G. W. R. Fernandes, A. M. Rodrigues, and C. A. Ferreira, "Professional Development and Use of Digital Technologies by Science Teachers: A review of theoretical frameworks," Res. Sci. Educ., vol. 48, pp. 1-36, 2018.

[12] N. C. Burbules and T. A. Callister, Watch IT: The Risks and Promises of New Information Technologies, Boulder, CO: Westview, 2000.

[13] S. K. Basak, M. Wotto, and P. Bélanger, "E-learning, m-learning and D-learning: Conceptual definition and comparative analysis," E-Learning Digit. Media, vol. 15, no. 4, pp. 191-216, 2018.

[14] B. Kanmani and K. M. Babu, "Leveraging technology in outcome-based education," in Proc. the International Conference on Transformations in Engineering Education, 2015, pp. 415-421.

[15] L. A. Cárdenas-Robledo and A. Peña-Ayala, "Ubiquitous learning: A systematic review," Telemat. Informatics, vol. 35, no. 5, pp. 1097-1132, 2018.

[16] L. R. M. McCutcheon, S. K. Alzghari, Y. R. Lee, W. G. Long, and R. Marquez, "Interprofessional education and distance education: A review and appraisal of the current literature," Curr. Pharm. Teach. Learn., vol. 9, no. 4, pp. 729-736, 2017.

[17] M. Gökalp, "A study on the effects of information technologies on university students," Procedia - Soc. Behav. Sci., vol. 9, pp. 501-506, 2010.

[18] A. Schüler, "The integration of information in a digital, multi-modal learning environment," Learn. Instr., December, pp. 0-1, 2017.

[19] Y. A. Zhang, Characteristics of Mobile Teaching and Learning, 2015.

[20] I. Peña-López, Innovating Education and Educating for Innovation The Power of Digital Technologies and Skills, 2016.

[21] B. Wu and T. Duan, "E-learning situations and cultivation strategies: An example from China," in Proc. IC4E 2018, 2018, pp. 15-19.

[22] S. Lundy, "Leveraging digital technology in social studies education," Portland State University, 2014.

[23] C. Watanabe, K. Naveed, and P. Neittaanmäki, "Co-evolution between trust in teachers and higher education toward digitally-rich learning environments," Technol. Soc., vol. 48, pp. 70-96, 2017.

[24] C. Liu, Y. Kuang, N. Huang, and X. Liu, "An empirical research on evaluation of low-carbon economy in Guangdong province, China : Based on 'production, life and environment," Low Carbon Econ., vol. 5, December, pp. 139-152, 2014.

[25] B. Yang, "China's low-carbon economy development and carbon finance market supervision mechanism," Low Carbon Econ., vol. 8, no. 4, pp. 97-105, 2017.

[26] D. Moher et al., "Preferred reporting items for systematic reviews and meta-analyses: The PRISMA statement," PLoS Med., vol. 6, no. 7, 2009.

[27] J. P. Vandenbroucke et al., "Strengthening the reporting of observational studies in epidemiology (STROBE): Explanation and elaboration," PLoS Med., vol. 4, no. 10, pp. 1628-1654, 2007.
[28] L. J. Chanlin, J. C. Hong, J. S. Horng, S. H. Chang, and H. C. Chu, "Factors influencing technology integration in teaching: A Taiwanese perspective," Innov. Educ. Teach. Int., vol. 43, no. 1, pp. 57-68, 2006.

[29] S. V. McLaren, "Exploring perceptions and attitudes towards teaching and learning manual technical drawing in a digital age," Int. J. Technol. Des. Educ., vol. 18, no. 2, pp. 167-188, 2008.

[30] S. Chatarajupalli, B. P. Tv, and S. R. K, "Leveraging technology for creating awareness of problem- solving skills to engineering students," pp. 238-239, 2010.

[31] S. Aloraini, "The impact of using multimedia on students' academic achievement in the College of Education at King Saud University," $J$. King Saud Univ. - Lang. Transl., vol. 24, no. 2, pp. 75-82, 2012.

[32] S. J. Zuiker, "Educational virtual environments as a lens for understanding both precise repeatability and specific variation in learning ecologies," Br. J. Educ. Technol., vol. 43, no. 6, pp. 981-992, 2012.

[33] D. K. Wentworth and J. H. Middleton, "Technology use and academic performance," Comput. Educ., vol. 78, pp. 306-311, 2014.

[34] M. M. H. Khan and J. C. L. Chiang, "Using mobile devices \& social media in supporting engineering education," in Proc. 2014 IEEE Glob. Eng. Educ. Conf., no. April, pp. 1077-1081, 2014.

[35] E. Christmann, "A comparison of the univariate statistics course achievement between students enrolled in online and traditional settings," E-Learning Digit. Media, vol. 14, no. 6, pp. 323-330, 2015.

[36] R. Daud, Z. A. Jalil, and M. N. F. M.Gunawan, "Community college students' perception towards digital learning In Malaysia," Procedia Soc. Behav. Sci., vol. 195, pp. 1798-1802, 2015.

[37] M. L. Sevillano-Garcí and E. Vázquez-Cano, "The impact of digital mobile devices in higher education," Educ. Technol. Soc., vol. 18, no. 1, pp. 106-118, 2015.

[38] S. Paek, D. L. Hoffman, and J. B. Black, "Perceptual factors and learning in digital environments," Educ. Technol. Res. Dev., vol. 64, no. 3, pp. 435-457, 2016.

[39] C. M. Tang and L. Y. Chaw, "Digital literacy: A prerequisite for effective learning in a blended learning environment?" Electron. J. e-Learning, vol. 14, no. 1, pp. 54-65, 2016.

[40] M. A. Camilleri and A. C. Camilleri, "Digital learning resources and ubiquitous technologies in education," Technol. Knowl. Learn., vol. 22 , no. 1 , pp. $65-82,2017$

[41] C. Ball, J. Francis, K.-T. Huang, T. Kadylak, S. R. Cotten, and R. V. Rikard, "The physical-digital divide: Exploring the social gap between digital natives and physical natives," J. Appl. Gerontol., p. $073346481773251,2017$.

[42] M. G. Stork, "Implementing a digital learning initiative: A case study in K-12 classrooms," J. Form. Des. Learn., vol. 2, pp. 36-48, 2017.

[43] P. Saxena et al., "Assessment of digital literacy and use of smart phones among Central Indian dental students," J. Oral Biol. Craniofacial Res., vol. 8, no. 1, pp. 40-43, 2018.

[44] M. Wiklund and A. Andersson, "Student-initiated use of technology Friend and foe," E-Learning Digit. Media, vol. 15, no. 1, pp. 3-16, 2018.

[45] K. Li, K. Darr, and F. Gao, "Enriching classroom learning through a microblogging-supported activity," E-Learning Digit. Media, vol. 15, no. 2, pp. 93-107, 2018.

[46] B. Means, "Technology and education change: Focus on student learning," J. Res. Technol. Educ., vol. 42, no. 3, pp. 285-307, 2010.

[47] Y. T. Sung, K. E. Chang, and T. C. Liu, "The effects of integrating mobile devices with teaching and learning on students' learning performance: A meta-analysis and research synthesis," Comput. Educ., vol. 94, pp. 252-275, 2016.

[48] M. Görke, V. Bellmann, J. Busch, and P. Nyhuis, "Employee qualification by digital learning games," Procedia Manuf., vol. 9, pp. 229-237, 2017.

[49] M. Ronchetti, G. Chiozzi, and R. Gris, "eSchooling: An ICT-based approach to competence-based education," Encyclopaideia, vol. 19, no. 42, pp. 43-65, 2015.

[50] V. Geiger, S. Dole, and M. Goos, "The role of digital technologies in numeracy," in Proc. 35th Conf. Int. Gr. Psychol. Math. Educ., vol. 2, May 2013, pp. 385-392, 2011.

[51] F. Soualah-Alila, C. Nicolle, and F. Mendes, Towards a Methodology for Semantic and Context-Aware Mobile Learning, Third edit. IGI Global, 2013.

[52] M. Olsson, P. Mozelius, and J. Collin, "Visualisation and gamification of e-Learning and programming education," Electron. J. e-Learning, vol. 13 , no. 6 , pp. 441-454, 2015.

[53] N. Dabbagh, L. Technologies, A. Kitsantas, and E. Psychology, "Personal learning environments, social media, and self-regulated 
learning: A natural formula for connecting formal and informal learning," Internet High. Educ., vol. 15, no. 1, pp. 3-8, 2012.

[54] M. Rani, K. V. Srivastava, and O. P. Vyas, "An ontological learning management system," Comput. Appl. Eng. Educ., vol. 24, no. 5, pp. 706-722, 2016.

[55] S. Behera, "E- and m-learning: A comparative study," Int. J. New Trends Educ. Their Implic., no. July, pp. 65-78, 2013.

[56] X. T. R. Kong, G. W. Chen, G. Q. Huang, and H. Luo, "Ubiquitous auction learning system with TELD (teaching by examples and learning by doing) approach: A quasi-experimental study," Comput. Educ., vol. 111, no. 3688, pp. 144-157, 2017.

[57] E. Novak, "A critical review of digital storyline-enhanced learning," Educ. Technol. Res. Dev., vol. 63, no. 3, pp. 431-453, 2015.

[58] S. Talib, "Social media pedagogy: Applying an interdisciplinary approach to teach multimodal critical digital literacy," E-Learning Digit. Media, vol. 15, no. 2, pp. 55-66, 2018.

[59] U. Köse, "A blended learning model supported with Web 2.0 technologies," Procedia - Soc. Behav. Sci., vol. 2, no. 2, pp. 2794-2802, 2010.

[60] M. T. Al-Hariri and A. A. Al-Hattami, "Impact of students' use of technology on their learning achievements in physiology courses at the University of Dammam," J. Taibah Univ. Med. Sci., vol. 12, no. 1, pp. $82-85,2017$.

[61] T. J. B. Blayone, R. vanOostveen, W. Barber, M. DiGiuseppe, and E. Childs, "Democratizing digital learning: theorizing the fully online learning community model," Int. J. Educ. Technol. High. Educ., vol. 14, no. 1, 2017.

[62] D. Ifenthaler, "Designing effective digital learning environments: Toward learning analytics design," Technol. Knowl. Learn., vol. 22, no. 3, pp. 401-404, 2017.

[63] A. Littlejohn, H. Beetham, and L. Mcgill, "Learning at the digital frontier: A review of digital literacies in theory and practice," $J$. Comput. Assist. Learn., vol. 28, no. 6, pp. 547-556, 2012.

[64] S. Manca and M. Ranieri, "Is it a tool suitable for learning? A critical review of the literature on Facebook as a technology-enhanced learning environment," J. Comput. Assist. Learn., vol. 29, no. 6, pp. 487-504, 2013.

[65] J. H. lii et al., "The four ' $\mathrm{R}$ ' $\mathrm{s}$ of openness and ALMS analysis: Frameworks for open educational resources open educational resources," J. Open Distance Learn., vol. 25:1, no. April, pp. 37-44, 2010.

[66] F. Kruse, "Technology-based learning approaches _ skillsyouneed." 2018.

[67] V. Koller, S. Harvey, and M. Magnotta, "Technology-based learning strategies," Soc. Policy Res. Assoc., no. 510, pp. 1-44, 2005.

[68] H. Montrieux, R. Vanderlinde, T. Schellens, and L. Marez, "Teaching and learning with mobile technology: A qualitative explorative study about the introduction of tablet devices in secondary education," PLOS One, vol. 10, no. 12, pp. 1-17, 2015.

[69] D. Lalima and K. L. Dangwal, "Blended learning: An innovative approach," Univers. J. Educ. Res., vol. 5, no. 1, pp. 129-136, 2017.

[70] N. Bencheva, "Learning styles and e-learning face-to-face to the traditional learning," E-Learning, pp. 63-67, 2010.

[71] D. Lindquist, T. Denning, M. Kelly, R. Malani, W. G. Griswold, and B. Simon, "Exploring the potential of mobile phones for active learning in the classroom," in Proc. 38th SIGCSE Tech. Symp. Comput. Sci. Educ. - SIGCSE '07, p. 384, 2007.

[72] G. Chen and D. Kotz, "A survey of context-aware mobile computing research," Dartmouth Comput. Sci. Tech. Rep., vol. 3755, pp. 1-16, 2000.

[73] M. Mohanna, "Using knowledge engineering for modeling mobile learning systems," Universite' Laval, Canada, 2015.

[74] D. Graham, "PESTEL factors for e-learning revisited: The 4Es of tutoring for value added learning," E-Learning Digit. Media, vol. 15, no. 1 , pp. 17-35, 2018
Copyright ( $\odot 2019$ by the authors. This is an open access article distributed under the Creative Commons Attribution License which permits unrestricted use, distribution, and reproduction in any medium, provided the original work is properly cited (CC BY 4.0)

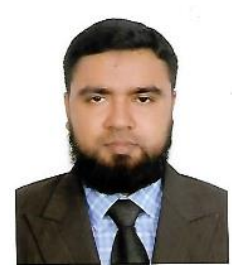

Md Nazirul Islam Sarker has recently obtained $\mathrm{PhD}$ from School of Public Administration, Sichuan University, Chengdu, China. He completed his bachelor of science in agriculture and the master in agricultural extension education from Bangladesh Agricultural University. He also completed MBA from commonwealth of learning. He also completed two diplomas in banking and Islamic banking. His research interest includes resilience, disaster management, livelihood and climate changes and education economy. He has published couple of scientific articles and one book on Poverty of Island Char Dwellers in Bangladesh. He is a member of several professional bodies. Mr. Sarker is now working as an editorial board member of several social sciences and public administration journals.

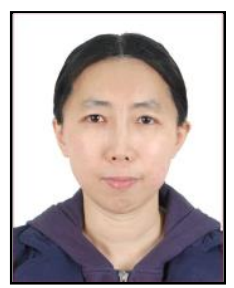

Min Wu is professor of School of Public Administration, Sichuan University. Her research interests include public policy, leadership, human resource management, educational administration, social governance etc. She is the advisor of master and Ph.D. candidates. She has been a visiting scholar in Texas A\&M University, Oxford University, Baylor University, Ewha Womans University, etc. She has a number of publications and has won many academic awards such as Emerald/IACMR Chinese Management Research Fund Award, Citation of Excellence, Excellent University Faculty, etc.

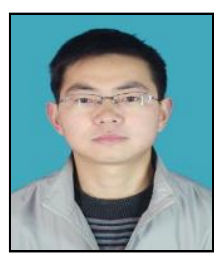

Qian Cao is $\mathrm{PhD}$ candidate of the School of Public Management, Sichuan University, Chengdu, China. He has completed master in national economics from Hubei MinZu University in 2010 . He is now working as intermediate lecturer in Hubei MinZu University. His research interest includes rural economy and land resource management.

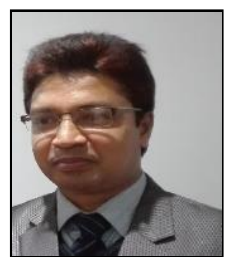

GM Monirul Alam holds a $\mathrm{PhD}$ degree in environmental and resource economics from the University of Southern Queensland (USQ), Australia. So far, he has published more than 40 scientific papers in reputed top ranked journals in the area of agricultural economics and climate change issues. He is serving as an adjunct research fellow at USQ, Australia. $\mathrm{He}$ is a faculty member of Bangabandhu Sheikh Mujibur Rahman Agricultural University, Bangladesh. He is also serving on the editorial board of couple of international scholarly journals. $\mathrm{He}$ is an active member of different professional societies and voluntary organizations

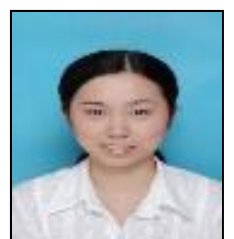

Dan Li is lecturer of Jinjiang College at Sichuan University. She is Ph.D. candidate in School of Public Administration at Sichuan University, Chengdu, China, majoring in Public Administration. She obtained her bachelor's degree in School of Public Administration at Sichuan University, majoring in public affairs management, and she obtained her master degree in School of Public Administration, Sichuan University, majoring in technological economics \& management.. 